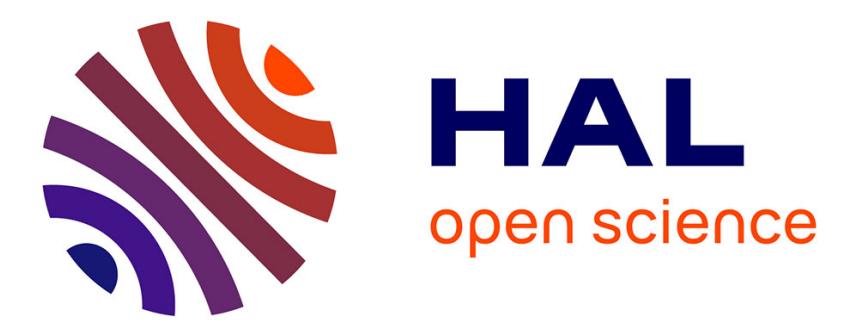

\title{
Supported and inserted monomeric niobium oxide species on/in silica: a molecular picture
}

Diana C Tranca, Anna Wojtaszek-Gurdak, Maria Ziolek, Frederik Tielens

\section{To cite this version:}

Diana C Tranca, Anna Wojtaszek-Gurdak, Maria Ziolek, Frederik Tielens. Supported and inserted monomeric niobium oxide species on/in silica: a molecular picture. Physical Chemistry Chemical Physics, 2015, 17 (34), pp.22402-22411. 10.1039/C5CP03450G . hal-01191751

\section{HAL Id: hal-01191751 \\ https://hal.sorbonne-universite.fr/hal-01191751}

Submitted on 2 Sep 2015

HAL is a multi-disciplinary open access archive for the deposit and dissemination of scientific research documents, whether they are published or not. The documents may come from teaching and research institutions in France or abroad, or from public or private research centers.
L'archive ouverte pluridisciplinaire HAL, est destinée au dépôt et à la diffusion de documents scientifiques de niveau recherche, publiés ou non, émanant des établissements d'enseignement et de recherche français ou étrangers, des laboratoires publics ou privés. 


\title{
Supported and Inserted Monomeric Niobium Oxide Species on/in Silica: A Molecular Picture
}

\author{
Diana C. Tranca ${ }^{1}$, Anna Wojtaszek-Gurdak ${ }^{2}$, Maria Ziolek ${ }^{2,}$ Frederik Tielens, ${ }^{3, *}$
}

1 Technische Universität Hamburg, Harburg, Chemische Reaktionstechnik, Eißendorfer Straße 3821073 Hamburg, Germany

${ }^{2}$ A. Mickiewicz University, Faculty of Chemistry Grunwaldzka 6, Poznan, Poland

${ }^{3}$ Sorbonne Universités, UPMC Univ Paris 06, UMR 7574, Laboratoire Chimie de la Matière Condensée, Collège de France, 11 place Marcelin Berthelot, 75231 Paris Cedex 05, France

*Corresponding authors:

F. Tielens, e-mail : frederik.tielens@upmc.fr, tel.: + 331 44276004, fax: + 331 44276033 


\begin{abstract}
The geometry, energetic, and spectroscopic properties of molecular structures of silicasupported niobium oxide catalysts are studied using periodic density functional calculations (DFT) and compared with experimental data. The calculations are done for $\mathrm{Nb}$ oxide species inserted or grafted in/on an amorphous hydroxylated silica surface. Different positions of the $\mathrm{Nb}$ atom/atoms in the silica structure have been investigated. By means of DFT calculations the geometry and the degree of hydration of $\mathrm{Nb}$ oxide species with oxidation state +5 have been studied. The local $\mathrm{Nb}$ geometry depends on different parameters such as: the number of $\mathrm{Nb}-\mathrm{O}-\mathrm{Si}$ groups vs $\mathrm{Nb}-\mathrm{O}-\mathrm{H}$ groups; the $\mathrm{H}$ bonds formation and the distance between $\mathrm{Nb}$ atoms. The interaction between the oxide and silanol groups occurs by formation of $\mathrm{Si}-\mathrm{O}-\mathrm{Nb}$ bonds with chemically and thermally stable Brønsted and Lewis acid sites. UV-vis, Reflection absorption infrared vibrational spectra (RAIRS) as well as various thermodynamic properties have also been investigated in order to get a better insight into the system studied and to provide support to possible experimental studies.
\end{abstract}

Keywords: Niobium, mesoporous molecular sieves, Ab Initio periodic DFT. 


\section{Introduction}

Niobium compounds and materials are important catalysts for various reactions ${ }^{1-7}$. They remarkably enhance catalytic activity and prolong catalyst life when small amounts are added to known catalysts. Generally speaking, niobium oxide and mixed oxides including: $\mathrm{Nb}_{2} \mathrm{O}_{5}-\mathrm{SiO}_{2} ; \mathrm{Nb}_{2} \mathrm{O}_{5}-\mathrm{Al}_{2} \mathrm{O}_{3}, \mathrm{Nb}$-zeolite, mesoporous Nb-MCM-41, Nb-layer compounds, etc. have redox properties, acidic properties and/or photosensivities. ${ }^{7,8}$

The characterization of the niobium phase on the silica surface has also been the subject of several studies. ${ }^{9-15}$ Niobium can form layers of $\mathrm{Nb}_{2} \mathrm{O}_{5}$, islands (clusters), oligomers, dimers and monomers on silica.

The synthesis and characterization of niobium(V) oxide grafted on a silica gel surface have been of great interest over the last few years. ${ }^{16-22}$ Niobia supported catalysts exhibits different properties compared to the bulk compound. ${ }^{7,} 18$ The experimental preparation method, niobia concentration, and thermal treatments may change interactions between niobia and silica. ${ }^{18}$ It has been reported that the deposited monolayer phase is stable at elevated temperature $(\mathrm{T}=873 \mathrm{~K})$. The Lewis acid sites of the surface are also considerably more stable than those found in the bulk phase. ${ }^{16,23,24}$

The interaction of niobium oxide with other oxides to form a dispersed surface phase has led to the formation of composite oxides with unusual structural and acidic characteristics, which are important as catalysts or catalytic supports. In particular photocatalytic activity has been reported for silica-supported niobium and layered niobate catalysts. ${ }^{17,25,26}$

The interaction between the oxide and silanol groups occurs by formation of $\mathrm{Si}-\mathrm{O}-\mathrm{Nb}$ bonds with chemically and thermally stable Brønsted and Lewis acid sites. These surface acid sites exhibit a great affinity for organic molecules which have carboxylic groups in their structure, forming stable $\mathrm{Nb}-\mathrm{OOC}$ - bonds. They also play an important role in the interaction with hydrogen peroxide towards the formation of peroxo and superoxo active species ${ }^{27}$. The metal complexes used in synthesis lead to a well-defined surface. The catalytic behavior changed depending on the structure. ${ }^{18,28}$

The dispersion of niobia over large surface area supports favors the enhancement of metal active sites. However, the addition of niobia onto the support decreased the total surface area but also provided less irregularity. ${ }^{29}$ 
At low loadings silica supported niobium show monomeric $\mathrm{Nb}$ oxide species difficult to characterize due to the spectral overlap of the $\mathrm{Nb}-\mathrm{O}$ and $\mathrm{Si}-\mathrm{O}$ vibrations. ${ }^{30,31}$ In order to shed some light on this complex situations quantum chemical calculations are an adequate investigation tool, as has been proved by our group on similar systems. ${ }^{32-37}$

An important obstacle to model the silica support is its amorphous structure. Amorphous silica exhibits a diversity of sites, especially in hydrous conditions: there are terminal and geminal silanols, and diversity in $\mathrm{H}$ bond connectivity. Moreover, a reliable model needs the presence of the typical siloxane ring size distribution in order to account for the coupled movement of silicon atoms. A representative first principles based model has been proposed earlier for the hydroxylated amorphous silica surface ${ }^{32}$ where the silanol density and the geminal/terminal ratio is that found on real samples, and accounts for the presence of different types of siloxane rings. ${ }^{18}$ This model is used in the present work to explore the grafting of a niobium precursor to the silica surface.

In the present study, a systematic theoretical investigation on molecular models of silica supported niobium oxide is performed. The nature of the niobia species is investigated from an inspection of the optimized geometry and its corresponding total energy. An atomistic thermodynamic model is used to account the effects of temperature on the free energy of the surfaces. This allows estimating the relative stability of the different species as a function of the temperature and hydration conditions. Finally, vibrational spectra are calculated and carefully compared with experimental results.

\section{Methodology}

\section{$\underline{\text { Computational details }}$}

All geometry optimizations are performed using $a b$ initio plane-wave pseudopotential approach as implemented in VASP ${ }^{38,39}$. The Perdew-Burke-Ernzerhof (PBE) functional ${ }^{40,41}$ has been chosen to perform the periodic DFT calculations with an accuracy on the overall convergence tested elsewhere ${ }^{33,34,42-44}$. The valence electrons are treated explicitly and their interactions with the ionic cores are described by the Projector Augmented-Wave method (PAW) ${ }^{45,46}$, which allows to use a low energy cut off equal to $500 \mathrm{eV}$ for the plane-wave basis. The Gamma point is used in the Brillouinzone integration. The positions of all the atoms in the super cell are relaxed until the 
total energy differences decrease below $10^{-4} \mathrm{eV}$. The atom positions as well as the unit cell have been relaxed.

Vibrational spectra have been calculated for selected surface species within the harmonic approximation. Only the niobium center and its first and second neighbors (O$\mathrm{Si}$ and $\mathrm{OH}$ groups) were allowed to move, the support was kept fixed. The Hessian matrix is computed by the finite difference method followed by a diagonalization procedure. The eigenvalues of the resulting matrix lead to the frequency values. The assignment of the vibrational modes is done by inspection of the corresponding eigenvectors.

\section{$\underline{\text { Model description }}$}

The silica model structure is described and characterized in our previous work ${ }^{44}$, (Fig. 1), and has been used in the study of vanadium oxide ${ }^{32}$, chromium oxide ${ }^{35,}{ }^{37}$, molybdenum oxide ${ }^{36}$ and gold ${ }^{33,34}$ grafting on silica. The niobium precursor is modeled by a $\mathrm{NbO}(\mathrm{OH})_{3}$ unit. This species is added to the silica unit cell (dimensions $12.77 \times$ $17.64 \times 25.17 \AA^{3}$ ) resulting in a niobium coverage of 0.44 atoms $\mathrm{nm}^{-2}$. The coverage is used to confront the results obtained for the high coverage $\mathrm{Nb}$ sample used in the work of Burcham et al. ${ }^{13}$ (0.33 atoms $\left.\mathrm{nm}^{-2}\right)$ and to the $10 \% \mathrm{Nb}$ loaded MCM-41-sample of Gao et $\mathrm{al}^{31}\left(0.26\right.$ atoms $\left.\mathrm{nm}^{-2}\right)$.

In the cases when two $\mathrm{Nb}$ atoms are inserted on the silica surface, the unit cell dimensions were doubled in order to keep the Nb loading constant: $12.47 \times 34.93 \times$ $24.52 \AA^{3}$. 

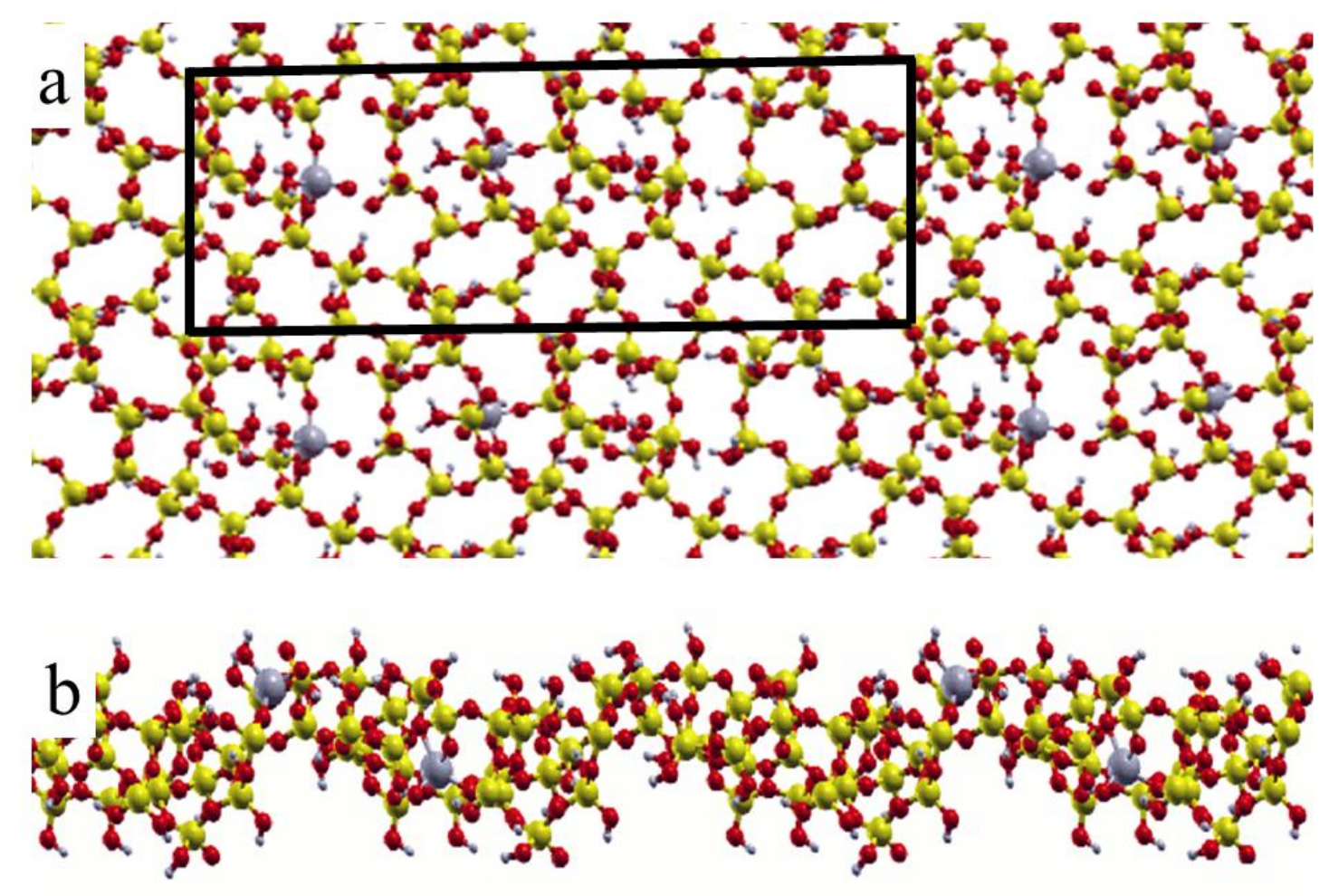

Figure 1. Model for the amorphous silica surface used in this work, for two supported $\mathrm{Nb}$ oxide species grafted onto silica surface showing the double unit cell dimensions, $\mathrm{a}$ : top view and b: side view of Structure 1. Color code: H: white; O: light red; Si: light orange; $\mathrm{Nb}$ : light gray.

The model precursor $\mathrm{H}_{3} \mathrm{NbO}_{4}$ is grafted by dehydration of surface silanols, following the reaction:

$$
\mathrm{H}_{3} \mathrm{NbO}_{4}+\mathrm{SiO}_{2}\left(\mathrm{H}_{2} \mathrm{O}_{\text {surf }}\right)_{13} \rightarrow \mathrm{OxNb}(\mathrm{OH})_{\mathrm{y}}-\mathrm{SiO}_{2}\left(\mathrm{H}_{2} \mathrm{O}_{\text {surf }}\right)_{13-\mathrm{n}}+\mathrm{n} \mathrm{H}_{2} \mathrm{O}
$$

where $\mathrm{n}$ is the number of water molecules eliminated and varies between 1 and $3, \mathrm{x}$ is the number of $\mathrm{Nb}=\mathrm{O}$ groups and, $\mathrm{y}$ is the number of $\mathrm{Nb}-\mathrm{OH}$ groups, with the condition that $\mathrm{x}+\mathrm{y}=4-\mathrm{n}$, due to the oxidation state of niobium. The oxidation state of $\mathrm{Nb}$ is in our models always equal to +5 , and is not mentioned further in the text. Theoretically up 
to four silanols may be involved in the reaction yielding different modes of grafting: mono, di, tri and tetra.

Several geometrical configurations are systematically investigated. Structures involving the different silanol types: isolated $(\mathrm{Si}-\mathrm{OH})$, vicinal $(\mathrm{HO}-\mathrm{Si}-\mathrm{O}-\mathrm{Si}-\mathrm{OH})$, geminal $(\mathrm{HO}-\mathrm{Si}-$ $\mathrm{OH}$ ) and isolated (two Si-OH groups not directly connected), on the surface were considered. Due to the flexibility of the silica surface, these species can be easily accommodated, and only the most important and interesting are discussed here.

\section{Experimental conditions}

\section{Preparation of materials}

Mesostructured cellular foam (MCF) was prepared by one-pot synthesis method according to Schmidt-Winkel et al. ${ }^{47}$ and Margolese et al. $^{48}$, whereas NbMCF was obtained via the modified method shown in ${ }^{49}, 50$. Firstly, Pluronic P123 (poly(ethylene glycol)-block-poly(propylene glycol)-block-poly(ethylene glycol)-block) (8 g, 1.4 mmol) was dissolved in $300 \mathrm{~cm}^{3}$ of $0.7 \mathrm{M} \mathrm{HCl}$ solution at 308-313 K. Secondly, 1,3,5trimethylbenzene (Aldrich) $\left(4 \mathrm{~g}, 33.28 \mathrm{mmol}\right.$ ) and $\mathrm{NH}_{4} \mathrm{~F}$ (Aldrich) (0.0934 g, 2.52 mmol) were added under vigorous stirring. Following $1 \mathrm{~h}$ of stirring, TEOS (Fluka) (17.054 g, $81.99 \mathrm{mmol})$ was added. The final mixture was stirred at $308-313 \mathrm{~K}$ for $20 \mathrm{~h}$ and then transferred into a polypropylene bottle $\left(500 \mathrm{~cm}^{3}\right)$ and heated at $373 \mathrm{~K}$ under static conditions for $24 \mathrm{~h}$. The solid product was recovered by filtration, washed with distilled water and dried at room temperature. The template was removed from the assynthesized material by calcination at $773 \mathrm{~K}$ for $8 \mathrm{~h}$ under static conditions. For the preparation of $\mathrm{NbMCF}$ (in one pot method - isomorphous $\mathrm{Nb}$ substitution) ammonium niobate(V) oxalate hydrate $\left(\mathrm{C}_{4} \mathrm{H}_{4} \mathrm{NNbO}_{9}\right.$ (Aldrich)) was also added to the gel while keeping $\mathrm{Si} / \mathrm{Nb}$ molar ratio $=30$ (10 min after TEOS admission $)$.

Niobium was also included by the wetness impregnation of MCF (postsynthesis grafting; $5 \mathrm{wt} \%$ of $\mathrm{Nb}$ ) with ammonium niobate(V) oxalate hydrate. The obtained material is labelled as $\mathrm{Nb} / \mathrm{MCF}$.

Niobiosilicate used as pillars for MCM-22 zeolite (obtained according to ${ }^{51}$ was prepared by mixing of TEOS and niobium(V) ethoxide (Aldrich) with the swelled (by 
hexadectyltrimethylammonium chloride) zeolite (MCM-22 : TEOS : Nb-ethoxide $=1$ : 5 : 0.19). The mixture was stirred at $363 \mathrm{~K}$ for $24 \mathrm{~h}$, filtered and washed with distilled water, dried at $333 \mathrm{~K}$ and finally calcined at $813 \mathrm{~K}$ for $5 \mathrm{~h}$.

\section{$\underline{\mathrm{UV}-\mathrm{Vis} \text { Spectroscopy }}$}

UV-Vis spectra were recorded on a Varian-Cary 300 Scan UV-visible spectrophotometer with an integrated sphere CA-30I. Catalysts, dehydrated at $673 \mathrm{~K}$ for $2 \mathrm{~h}$, in the form of powders were placed into a cell equipped with a quartz window. The Kubelka-Munk function $(\mathrm{F}(\mathrm{R}))$ was used to convert reflectance measurements into equivalent absorption spectra using the reflectance of SPECTRALON as a reference.

\section{$\underline{\text { Infrared measurements }}$}

Infrared spectra were recorded with a Bruker Vector 22 FTIR spectrometer using an in situ cell. Samples were pressed under low pressure into a thin wafers of ca. $8 \mathrm{mg} \mathrm{cm}^{-2}$ and placed inside the vacuum cell. Catalysts were evacuated at $623 \mathrm{~K}$ during $2 \mathrm{~h}$.

\section{Results and Discussion}

\section{Geometry and Energetics}

\section{$\underline{\mathrm{Nb}(\mathrm{V}) \text { oxide species grafted on } \mathrm{SiO}_{2} \text { surface }}$}

$\mathrm{Nb}$ oxide can be grafted on different sites on the silica surface. A detailed study of the all the possibilities has been performed for Mo oxide ${ }^{36}$. From this study it was concluded that the selected site, also used for $\mathrm{V}$ and $\mathrm{Cr}$, is representative as a mean environment at the surface, with the possibilities to graft the oxide on up to three silanol groups. The adsorption process on Silica of other transition metal precursors such as for Ni has been investigated as well. ${ }^{52,53}$

Figure 2 shows (structure: A) mono-, (structure: B) di-, (structure: C and D) tri- and (structure: E) tetra-grafted niobium oxide species on silica support. For mono- and digrafted niobia, the vicinal silanol sites are preferred, in agreement with earlier studies on 
the reactivity of silanol groups. ${ }^{36}$ Tri- and tetra-grafted species need the presence of three and four neighboring silanol sites, respectively. The preference of mono-grafted species to the vicinal $\mathrm{HO}-\mathrm{Si}-\mathrm{O}-\mathrm{Si}-\mathrm{OH}$ sites may be due to the formation of $\mathrm{H}$-bonds between the $\mathrm{Nb}-\mathrm{OH}$ groups and surface silanol groups which stabilize the conformations.

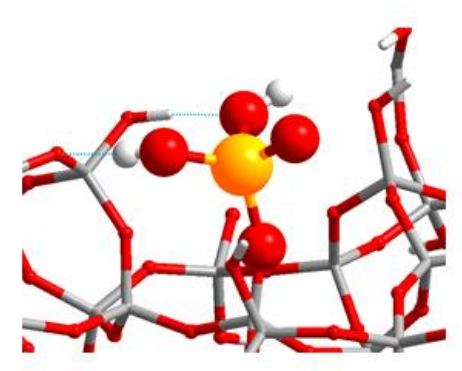

A

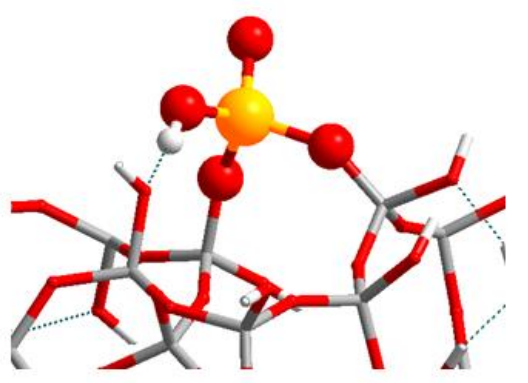

$\mathrm{B}$

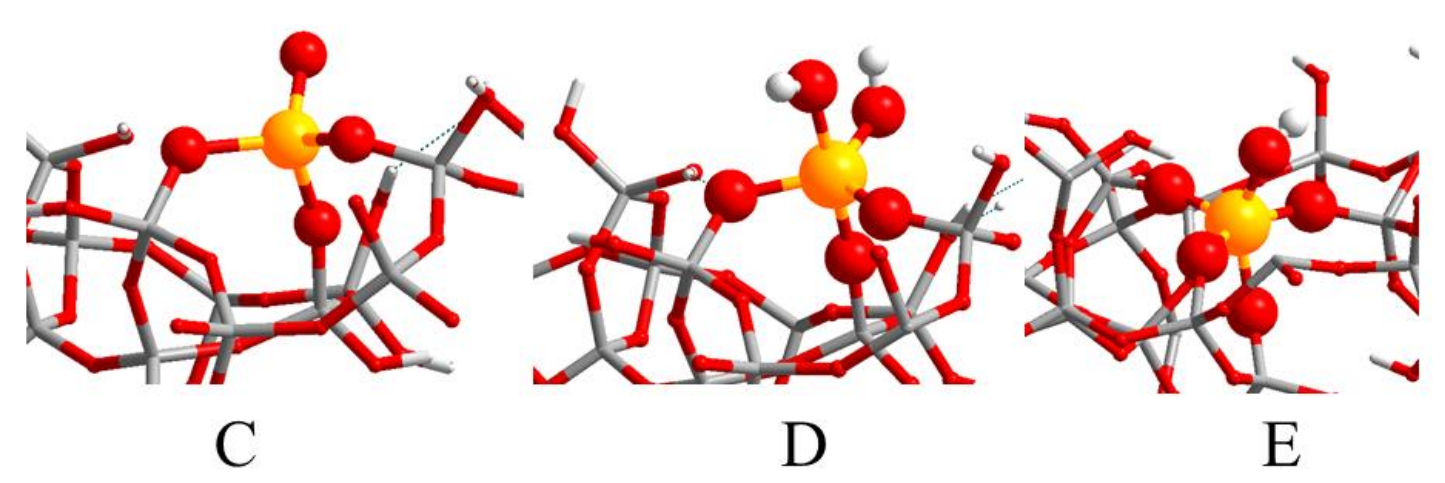

Figure 2. Optimized molecular models for the $\mathrm{Nb}$-oxide species grafted onto silica surface. Color code: $\mathrm{H}$ : white; $\mathrm{O}$, red; $\mathrm{Si}$ : gray; $\mathrm{Nb}$ : orange.

According to the calculated energy values for reaction (eq. 1) shown in Table 1, the mono- and tetra-grafted niobium species are the highest exothermic configurations, species A and E. However it should be noted that the tetra-grafted species (E) are the same as the substituted one ( $\mathrm{Si}$ by $\mathrm{Nb}$ ). Since geometrically the probability to have four silanol groups close together in such a configuration is negligible on amorphous silica surface it should be considered as substituted site and for clarity in this paper it will be called the substituted form. The other properties should be considered if silica ordered 
mesoporous molecular sieves (e.g. SBA-125, MCF) are used as supports for niobium species. For such structures (e.g. MCF molecular foams containing cavities) the formation of tetra-grafted species is probable during grafting and isomorphous substitution as well. Experimentally, by the use of UV-Vis spectroscopy (Fig. 3) one cannot distinguish the coordination of niobium incorporated into MCF structure by impregnation and by the substitution during the synthesis ( $\mathrm{Nb} / \mathrm{MCF}$ and $\mathrm{NbMCF}$, respectively). In both cases two UV bands are observed, at ca 220 and $260 \mathrm{~nm}$. Both come from charge transfer from oxygen to niobium atoms (at low coordination states; tetra and penta) located at the different surroundings. The higher coordination state (octahedral) typical of bulk niobium oxide should give the band at ca $330 \mathrm{~nm}$. Such a band is not visible in the spectra presented in Fig. 3. One can assign the observed UV bands to structures $\mathrm{A}$ and $\mathrm{E}$ in the theoretical models, i.e. the most stable structures.

The other picture appears when amorphous niobosilica is prepared and located as pillars in MCM-22 zeolite. UV-Vis spectrum (Fig. 4) reveals only one UV band centered at ca $220 \mathrm{~nm}$. In the case of amorphous silica surface (not structured in cavities like in MCF) the probability to have four silanol groups close together in the configuration $\mathrm{E}$ is negligible. Therefore the observed band can be assign to niobium mono grafted in the configuration A.

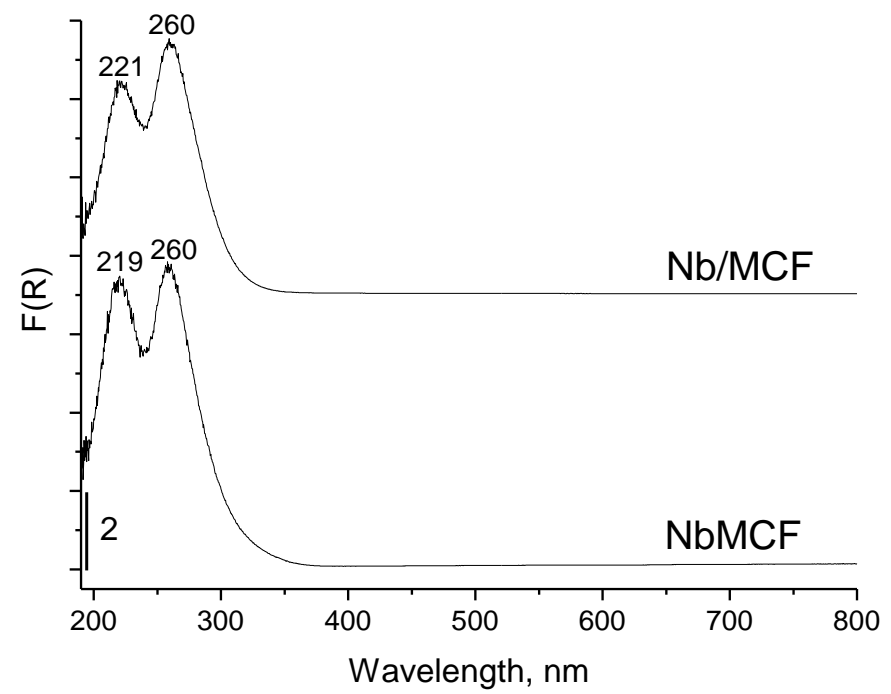

Figure 3. UV-Vis spectra of niobium containing MCF obtained by the impregnation $(\mathrm{Nb} / \mathrm{MCF})$ and isomorphous substitution during the synthesis (NbMCF) 
Table 1. Reaction energy at $0 \mathrm{~K}$ in vacuum, calculated using equation (1) for the grafting of different $\mathrm{Nb}$ and $\mathrm{V}$ oxide models. (Values in $\mathrm{eV}$ )

\begin{tabular}{|c|c|c|c|}
\hline Structure & H-Bonds & $\begin{array}{l}\Delta E_{\text {react }} \\
\text { For Niobium (this } \\
\text { work) }\end{array}$ & $\begin{array}{l}\Delta E_{\text {react }} \\
\text { for } \\
\text { Vanadium }^{32}\end{array}$ \\
\hline A-V: Surface $+\mathrm{H}_{3} \mathrm{NbO}_{4}-1 \mathrm{H}_{2} \mathrm{O}$ & $\begin{array}{l}\mathrm{NbOH} \ldots \mathrm{O}(\mathrm{H}) \mathrm{Si} \\
\mathrm{Nb}(\mathrm{H}) \mathrm{O} \ldots \mathrm{HOSi}\end{array}$ & -0.77 & -0.66 \\
\hline$A-G$ & - & -0.34 & -0.30 \\
\hline A-I & - & -0.45 & -0.44 \\
\hline B-V: Surface $+\mathrm{H}_{3} \mathrm{NbO}_{4}-2 \mathrm{H}_{2} \mathrm{O}$ & - & -0.25 & -0.25 \\
\hline $\mathrm{B}-\mathrm{G}$ & $\begin{array}{l}\mathrm{Nb}=\mathrm{O} \ldots \mathrm{H} \\
\mathrm{NbOH} \ldots \mathrm{OHSi}\end{array}$ & -0.51 & -0.24 \\
\hline $\mathrm{C}:$ Surface $+\mathrm{H}_{3} \mathrm{NbO}_{4}-2 \mathrm{H}_{2} \mathrm{O}$ & - & -0.38 & +0.95 \\
\hline D: Surface $+\mathrm{H}_{3} \mathrm{NbO}_{4}-3 \mathrm{H}_{2} \mathrm{O}$ & $\mathrm{NbOH} \ldots(\mathrm{Nb}) \mathrm{OH}$ & +0.45 & - \\
\hline $\begin{array}{l}\mathrm{E}: \text { Surface }+\mathrm{H}_{3} \mathrm{NbO}_{4}-1 \mathrm{H}_{2} \mathrm{O} \\
\text { (substituted) }\end{array}$ & HO...HOSi & -0.95 & - \\
\hline
\end{tabular}

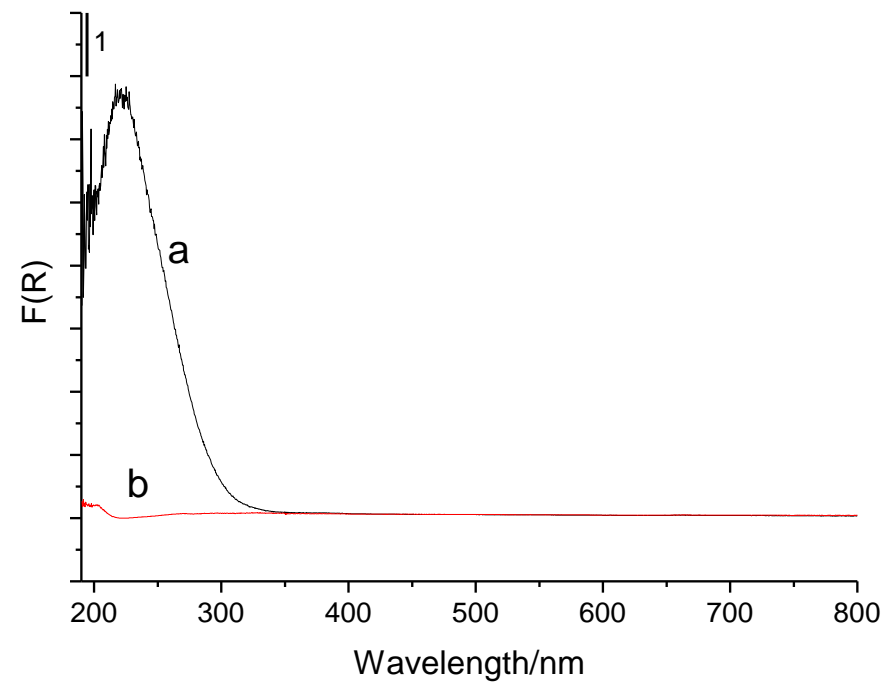

Figure 4. UV-Vis spectra of MCM-22 pillared with niobiosilica (a) and silica (b). 
The least stable structures are di- and tri-oxo-grafted species: B, C, and D.

Tri-grafted species need the presence of three neighboring silanol sites and no preference for a particular configuration is found. Species with bridging hydroxyl Nb$\mathrm{OH}-\mathrm{Si}$ groups and di-oxo species $(\mathrm{O}=\mathrm{Nb}=\mathrm{O})$ are clearly disfavored (not shown).

The bond lengths and bond angles have been calculated both for one and two $\mathrm{Nb}$ atoms grafted on silica surface (See Table 2). The optimized structures have a $\mathrm{Nb}=\mathrm{O}$ bond length of $1.76-1.79 \AA$ for one $\mathrm{Nb}$ atom and a value of $1.77 \AA$ for two $\mathrm{Nb}$ atoms grafted on silica surface, which is very close to the gas phase $\mathrm{Nb}_{2} \mathrm{O}_{5}$ molecule $(1.779 \AA)^{54}$ The niobyl bond is almost not influenced by the environment; only a small shortening can be noticed with increasing number of $\mathrm{Nb}-\mathrm{O}-\mathrm{Si}$ links. The bridging $\mathrm{Nb}-\mathrm{OSi}$ bond distances (1.85 - $2.13 \AA$ ) and the bond angle $\mathrm{Nb}-\mathrm{O}-\mathrm{Si}$ (between $126.4^{\circ}-171.4^{\circ}$ for one $\mathrm{Nb}$ atom, and $133.6^{\circ}-150.3^{\circ}$ for two $\mathrm{Nb}$ atoms), are independent of the nature of the grafting site. For the di- and tri- grafted sites one extra angle of around $125^{\circ}$ is observed. The $\mathrm{Nb}-\mathrm{OH}$ bonds are in the range of $1.92-2.03 \AA$ for one $\mathrm{Nb}$ atom and $1.86-1.93 \AA$ for two $\mathrm{Nb}$ atoms. The values obtained for the calculated $\mathrm{Nb}=\mathrm{O}$ bonds are in good agreement with the bond distance derived from RAMAN spectra ${ }^{55}$.

Table 2. Calculated selected geometrical parameters in niobia/silica systems (distances $\mathrm{d}$ in $\AA$, angles $\alpha$ in degrees).

\begin{tabular}{|c|c|c|c|}
\hline $\begin{array}{l}\text { Distance d } \\
\text { angle } \alpha\end{array}$ & $\mathrm{Nb}^{1}$ & $\mathrm{Nb}^{2}$ & Literature \\
\hline $\mathrm{d}(\mathrm{Nb}=\mathrm{O})$ & $1.76-1.79$ & 1.77 & $1.77^{54}$ \\
\hline $\mathrm{d}(\mathrm{Nb}-\mathrm{OSi})$ & $1.88-2.04$ & $1.85-2.13$ & - \\
\hline $\mathrm{d}(\mathrm{NbO}-\mathrm{Si})$ & $1.63-1.65$ & $1.61-1.74$ & - \\
\hline $\mathrm{d}(\mathrm{Nb}-\mathrm{OH})$ & $1.92-2.03$ & $1.86-1.93$ & - \\
\hline $\mathrm{d}(\mathrm{Nb}-\mathrm{Nb})$ & - & $5.08-12.7$ & - \\
\hline$\alpha(\mathrm{Nb}-\mathrm{O}-\mathrm{Si})$ & $126.4-171.4$ & $133.6-150.3$ & - \\
\hline$\alpha(\mathrm{Nb}-\mathrm{O}-\mathrm{H})$ & $115.0-136.9$ & $117.1-132.5$ & - \\
\hline
\end{tabular}


${ }^{2}$ Two $\mathrm{Nb}$ atoms in double unit cell with different inter-atomic $\mathrm{Nb}-\mathrm{Nb}$ distances.

Grafting of niobium oxide on silica surface has a relatively small effect on the silica framework. The largest distortion is observed for the bridging oxygen sites (Nb-OSi). Initially silica hydroxyl groups are displaced by $0.39 \AA$ after grafting for one $\mathrm{Nb}$ atom and by $0.48 \AA$ for the case of two $\mathrm{Nb}$ atoms inserted onto silica surface. For the case when two $\mathrm{Nb}$ atoms are grafted to the silica surface, the NbO-Si bond is slightly displaced by $0.1 \AA$ from their initial positions. The $\mathrm{Si}-\mathrm{O}-\mathrm{Si}$ angles range from $139.8^{\circ}$ to $155.5^{\circ}$ for the niobium silica surface which is close to the values of $130^{\circ}$ to $180^{\circ}$ for $\mathrm{Si}$ $\mathrm{O}-\mathrm{Si}$ angles of silica surfaces ${ }^{23}$. The Nb-O-Si angles range from $133.6^{\circ}$ to $150.3^{\circ}$.

In summary, the overall silica geometry is only slightly modified upon $\mathrm{Nb}$ oxide grafting. The same result was obtained for the grafting of vanadium oxides on silica surfaces $^{32}$.

Besides grafting one can also insert $\mathrm{Nb}$ into the silica framework. Experimentally it was shown by Ziolek et al. ${ }^{56}$ that the $\mathrm{Nb}$ species inserted into ordered mesoporous silica of MCM-41 type can form Lewis acid and base pairs after dehydration. In order to investigate the molecular structure of this particular situation, two $\mathrm{Nb}$ oxide sites were studied as a function of the distance between them. Table $\mathbf{3}$ and Figure $\mathbf{5}$ show the relative energies for the case when two $\mathrm{Nb}$ atoms are inserted into the silica surface.

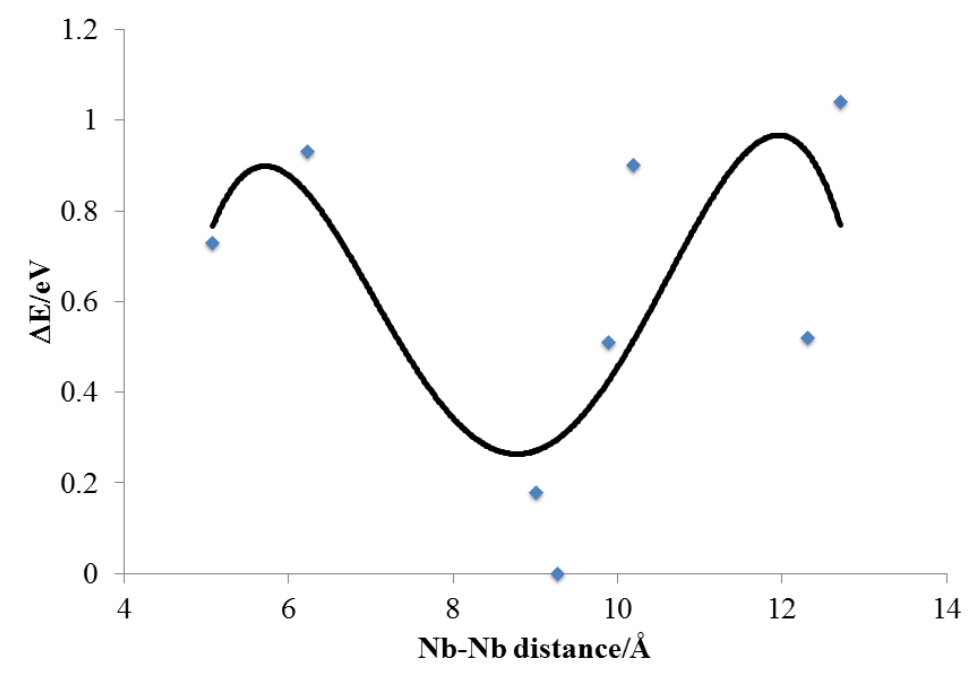


Figure 5. Relative energy between the most stable structures with two supported $\mathrm{Nb}$ oxide species grafted onto silica surface (Structure 1) vs. Nb-Nb distance in the silica model. A trend line is drawn in black.

Table 3. Relative Energies for the double unit cell with two $\mathrm{Nb}$ atoms. Energies in $\mathrm{eV}$ and distances in $\AA$, the index $n R$ of $\mathrm{Nb}$ corresponds to the size of the siloxane ring in which the substitution has been performed ( $\mathrm{n}=$ number of $\mathrm{Si}$ sites).

\begin{tabular}{|c|c|c|c|c|}
\hline Structure & $\Delta E$ & $\mathrm{Nb} \cdots \mathrm{Nb}$ Distances & Structure Description & H-Bonds \\
\hline 1 & 0.00 & 9.27 & $\mathrm{Nb}_{6 \mathrm{R}}+\mathrm{Nb}_{5 \mathrm{R}}$ & $\mathrm{Nb}=\mathrm{O} \cdots \mathrm{H}$ \\
\hline 2 & 0.18 & 9.01 & $\mathrm{Nb}_{6 \mathrm{R}}+\mathrm{Nb}_{4 \mathrm{R}}(1 \mathrm{SiOH})$ & $\mathrm{NbOH} \cdots \mathrm{OHSi}$ \\
\hline 3 & 0.51 & 9.89 & $\mathrm{Nb}_{6 \mathrm{R}}+\mathrm{Nb}_{4 \mathrm{R}}(2 \mathrm{SiOH})$ & $\mathrm{NbOH} \cdots \mathrm{OHSi}$ \\
\hline 4 & 0.52 & 12.31 & $\mathrm{Nb}_{6 \mathrm{R}}+\mathrm{Nb}_{4 \mathrm{R}}(1 \mathrm{SiOH})$ & $\mathrm{NbOH} \cdots \mathrm{OHSi}$ \\
\hline 5 & 0.73 & 5.08 & $\mathrm{Nb}_{6 \mathrm{R}}+\mathrm{Nb}_{4 \mathrm{R}}(2 \mathrm{SiOH})$ & $\begin{array}{l}\mathrm{SiOH} \cdots(\mathrm{Nb}) \mathrm{OH} \cdots \mathrm{OHSi} \\
(2 \mathrm{H}-\text { bonds })\end{array}$ \\
\hline 6 & 0.90 & 10.20 & $\mathrm{Nb}_{6 \mathrm{R}}+\mathrm{Nb}_{4 \mathrm{R}}(2 \mathrm{SiOH})$ & $\begin{array}{l}\mathrm{SiOH} \cdots(\mathrm{Nb}) \mathrm{OH} \cdots \mathrm{OHSi} \\
(2 \mathrm{H} \text {-bonds })\end{array}$ \\
\hline 7 & 0.93 & 6.23 & $\mathrm{Nb}_{6 \mathrm{R}}+\mathrm{Nb}_{4 \mathrm{R}}(2 \mathrm{SiOH})$ & - \\
\hline 8 & 1.04 & 12.71 & $\mathrm{Nb}_{6 \mathrm{R}}+\mathrm{Nb}_{4 \mathrm{R}}(2 \mathrm{SiOH})$ & - \\
\hline
\end{tabular}




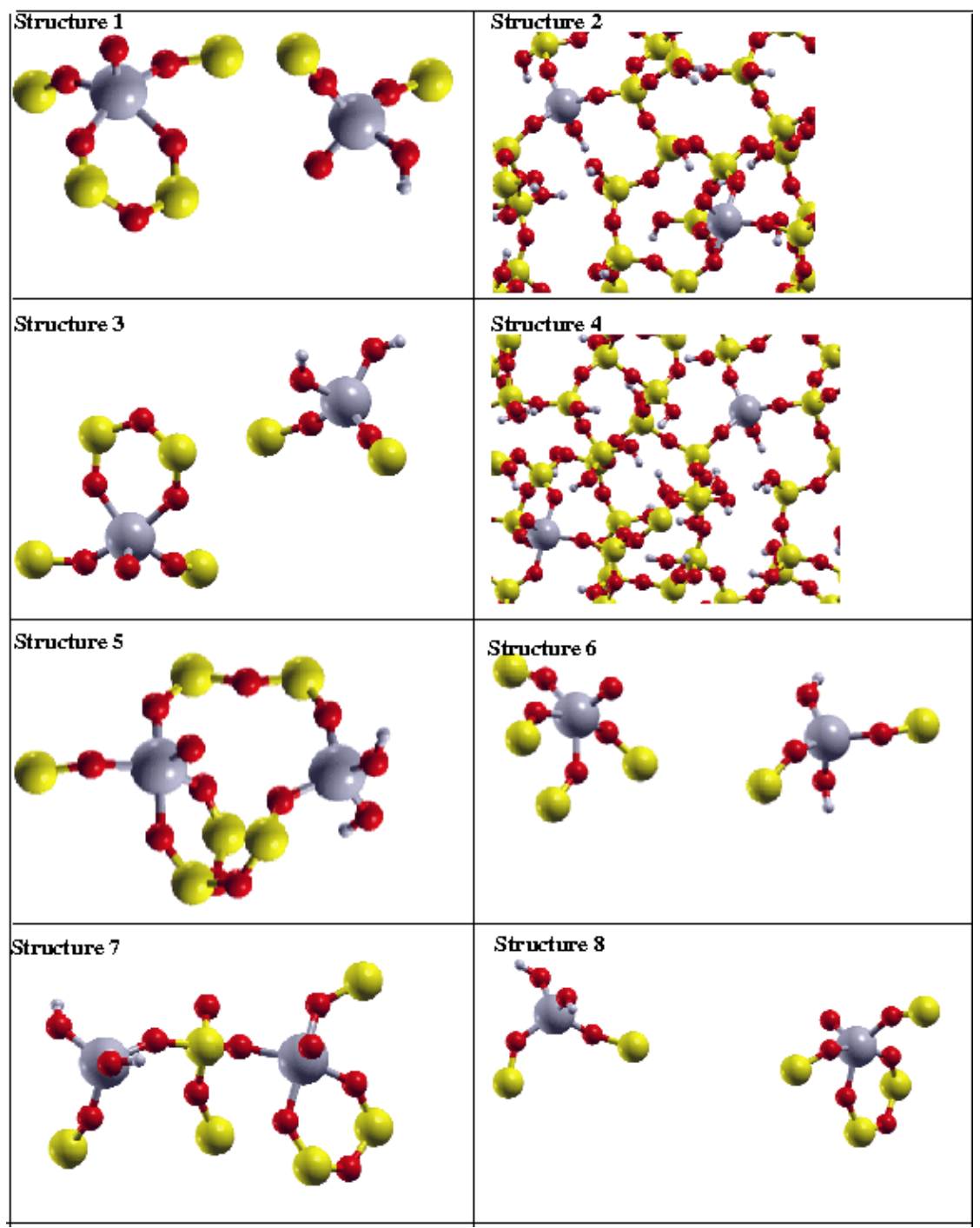

Figure 6. Most stable geometries for the structures with two supported $\mathrm{Nb}$ oxide species grafted onto silica surface. Color code: $\mathrm{H}$ : white; O: light red; Si: light orange; Nb: light gray.

The most stable structure (See Figure 6) is obtained when $\mathrm{Nb}$ is substituted in a siloxane ring containing $6 \mathrm{~T}$ atoms and $5 \mathrm{~T}$ atoms $\left(\mathrm{Nb}_{6 \mathrm{R}}+\mathrm{Nb}_{5 \mathrm{R}}\right.$ is formed). The next stable structures are observed for the formation of $\mathrm{Nb}_{6 \mathrm{R}}+\mathrm{Nb}_{4 \mathrm{R}}$. The number of $\mathrm{Nb}-\mathrm{OSi}$ and $\mathrm{Nb}-\mathrm{OH}$ groups can vary when $\mathrm{Nb}_{4 \mathrm{R}}$ is generated. For the $\mathrm{Nb}_{6 \mathrm{R}}+\mathrm{Nb}_{4 \mathrm{R}}$, the stability of the structures is determined by the following factors: numbers of $\mathrm{Nb}-\mathrm{OSi}$ groups; numbers of $\mathrm{Nb}-\mathrm{OH}$ groups; $\mathrm{H}$-bonds formation; distance between the two $\mathrm{Nb}$ atoms.

The most stable structures are those which have a large number of $\mathrm{Nb}-\mathrm{OSi}$ and $\mathrm{Nb}-\mathrm{OH}$ groups and implicitly $\mathrm{H}$ bonds formation. Between the $\mathrm{Nb}-\mathrm{OH}$ groups and surface 
silanol groups are formed H-bonds which stabilize the surface structure. The less stable structures are those which do not form $\mathrm{H}$-bonds (the $\mathrm{Nb}-\mathrm{OH}$ groups are pointed towards vacuum) and the distance between the $\mathrm{Nb}$ atoms is either too small or too large. An optimal $\mathrm{Nb}-\mathrm{Nb}$ distance is found around $9 \AA$ (See figure 5).

\section{Thermodymics and stability of the supported niobium oxide species}

Considering the reaction energy ( $\Delta E_{\text {react }}$, Table 1) as calculated according to reaction (1) for the best grafting modes (mono-, di-, tri-, and tetra-grafting), we obtain $-0.77,-0.51$, +0.45 for $n=1,2$ and 3 , respectively, and $-0.95 \mathrm{eV}$ in the case of substitution $(n=1)$. These values suggest that the grafting of the niobium complex is favored compared to the initial situation (hydroxylated silica and $\mathrm{O}=\mathrm{Nb}(\mathrm{OH})_{3}$ in the gas phase) for the monoand di-grafted species, as well as for the insertion (structure E), while it is endothermic for the tri-grafted one. The endothermicity of the reaction leading to the tri-grafted species means that the gain in energy due to the formation of three water molecules is not sufficient to counter-balance the cost of breaking three Si-OH bonds. Indeed, the present calculations report electronic energies only, which are identical to the free energy at $0 \mathrm{~K}$. Under given temperature $T$ and pressure $p$, the contributions of entropy and chemical potentials have to be taken into account in the free energies.

In order to get a more precise picture of the respective stabilities of the mono-, di- and tri-grafted species at the silica surface, we performed calculations using the atomistic thermodynamics approach. To take into account deviations in surface composition and the presence of gas phases, one introduces appropriate chemical potentials to calculate an approximation of the Gibbs free energy. Assuming that the surface is in thermodynamic equilibrium with the gas phase, the chemical potentials are related to a given temperature $T$ and pressure $p$. This procedure enables to extend the $0 \mathrm{~K}$ and zero pressure DFT results to experimentally relevant environments, thereby bridging the gap between ultra-high vacuum like conditions, and temperatures and gas phase pressures that are applied in realistic catalytic conditions. For this purpose the following equations are considered:

$$
\begin{aligned}
& \mathrm{ONb}(\mathrm{OH})_{2}(\mathrm{O}-\mathrm{Si})->\mathrm{ONb}(\mathrm{OH})(\mathrm{O}-\mathrm{Si})_{2}+\mathrm{H}_{2} \mathrm{O}_{\text {gas }} \\
& \mathrm{ONb}(\mathrm{OH})(\mathrm{O}-\mathrm{Si})_{2}->\mathrm{ONb}(\mathrm{O}-\mathrm{Si})_{3}+\mathrm{H}_{2} \mathrm{O}_{\text {gas }}
\end{aligned}
$$


It is assumed that the niobia/silica system is in contact with a gaseous water reservoir. From the electronic energy, the free energy of the water/niobia/silica interface under known thermodynamic conditions may be estimated following the approximations used in our earlier studies. ${ }^{36}$ They neglect the variation of the chemical potentials of the surfaces with the adsorption of water and the gas phase is modeled as a perfect gas. In the proposed scheme, the free energy of water (including the ZPE correction) in the gas phase is:

$$
\Delta G\left(\mathrm{H}_{2} \mathrm{O}\right)=E\left(\mathrm{H}_{2} \mathrm{O}\right)-\left(\left(\Delta H_{\mathrm{G}}-T \Delta S_{\mathrm{G}}(T)\right)+\mathrm{R} T \ln \left(\mathrm{p} / \mathrm{p}^{\circ}\right)\right)
$$

where $E\left(\mathrm{H}_{2} \mathrm{O}\right)$ is the electronic energy of water calculated at $0 \mathrm{~K}, \Delta H_{\mathrm{G}}$ and $\Delta S_{\mathrm{G}}(T)$ are the enthalpy and entropy of gaseous water, calculated with the Gaussian03 $\operatorname{code}^{57}$ as a function of the temperature, $p$ is the partial pressure of water vapor and $p^{\circ}$ is the standard pressure (1 bar).

Using the above mentioned formalism, the free energies of reactions (2) and (3) for the formation of the di- and tri-grafted niobium complexes from the mono-grafted one at equilibrium conditions, are then expressed as:

$$
\begin{aligned}
\Delta G_{2} & =E\left(\mathrm{ONb}(\mathrm{OH})(\mathrm{O}-\mathrm{Si})_{2}\right)+\Delta G\left(\mathrm{H}_{2} \mathrm{O}\right)-E\left(\mathrm{ONb}(\mathrm{OH})_{2}(\mathrm{Si}-\mathrm{O})\right) \\
\Delta G_{3} & =E\left(\mathrm{ONb}(\mathrm{O}-\mathrm{Si})_{3}\right)+\Delta G\left(\mathrm{H}_{2} \mathrm{O}\right)-E\left(\mathrm{ONb}(\mathrm{OH})(\mathrm{Si}-\mathrm{O})_{2}\right)
\end{aligned}
$$

In this approach, it is assumed that the energies of the mono- to di- and di- to tri-grafted transitions are independent of the degree of hydration of the silica surface. It is known from experiments that silanols are stable at silica surfaces up to $673 \mathrm{~K}$. Above this temperature, silanols begin to condensate into siloxane bridges. ${ }^{58}$ Thus, our model with a density of $5.8 \mathrm{OH} / \mathrm{nm}^{2}$ corresponding to conditions of a hydroxylated surface, holds up to the temperature of $673 \mathrm{~K}$.

Figure 7 shows the surface free energy $\Delta \Gamma$, defined as the free energy per surface area, of the grafted and the inserted (substituted) $\mathrm{Nb}$-complexes on/in the silica surface as a function of temperature $(T)$ for a water partial pressure $(p)$ equivalent to the ambient air water partial pressure $\left(\mathrm{p}_{\mathrm{w}}=1500 \mathrm{~Pa}\right)^{59}$. At these conditions, the mono-grafted model is the most stable up to $T=230 \mathrm{~K}$, followed by the digrafted structure in the range of 230 $660 \mathrm{~K}$ domain, finally at $T>660 \mathrm{~K}$ the trigrafted complex is found as the most stable configuration. These results are fully consistent with the experimental procedure used in 
the synthesis of niobia-supported catalysts by grafting methods. From the thermodynamic approach one may conclude that the most stable species at low temperature is the mono-grafted $\mathrm{ONb}(\mathrm{OH})_{2}(\mathrm{O}-\mathrm{Si})$ complex. This configuration corresponds to the fully hydrated niobia catalyst on the silica support. An increase in temperature or a decrease in hydration stabilizes the di-grafted $\mathrm{ONb}(\mathrm{OH})(\mathrm{O}-\mathrm{Si})_{2}$ complex. High temperatures favor the formation of the pyramidal $\mathrm{ONb}(\mathrm{O}-\mathrm{Si})_{3}$ arrangement. Nevertheless it should be noted that the penta-coordinated tri-grafted $\mathrm{Nb}$ species (C) with two hydroxyl groups is only $0.13 \mathrm{eV}$ less stable than the di-grafted species. In the same diagram (Fig. 7) we have plotted the curve for the inserted species E, which is stable until $350 \mathrm{~K}$ (at ambient air water pressure) after which one might expect possible segregation to the surface and transformation into a di-grafted species such as structure B. This hypothesis is of course only valid without the presence of any unbridgeable kinetic barrier.

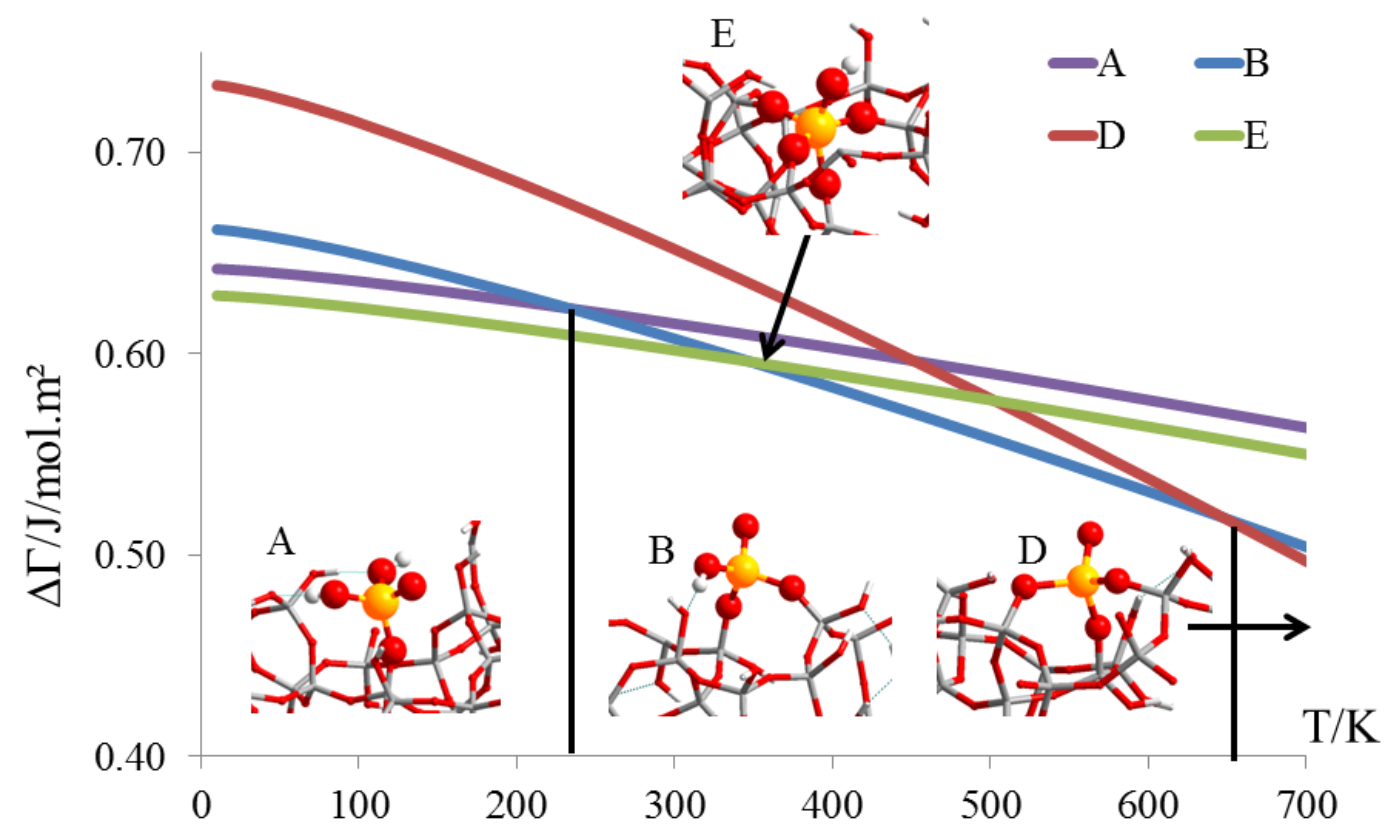

Figure 7. Phase diagram (surface energy vs. temperature) showing the stability ranges for the different grafting geometries.

\section{Vibrational frequency analysis and Infrared Analysis}

Table S1 and Table S2 (See Supplementary Material) show the vibrations calculated for the models $\mathrm{A}$ to $\mathrm{E}$ and the double $\mathrm{Nb}$ /double unit cell models, together with the 
assignment of the normal modes. The calculated values were not scaled but can easily be recalculated using the scaling factor to the experimental data using the value reported in ref. ${ }^{60}$. It should be noted that experimentally, the $\mathrm{SiO}_{2}$ spectra will be predominant over every individual $\mathrm{Nb}-\mathrm{O}$ vibration mode that is why theoretical calculations are indispensable to interpret the spectra.

Only calculated frequencies in the range $600-4000 \mathrm{~cm}^{-1}$ are reported. The region of $3000-4000 \mathrm{~cm}^{-1}$ is dominated by the hydroxyl vibrations. Values higher than $3660 \mathrm{~cm}^{-1}$ are assigned to free $\mathrm{NbO}-\mathrm{H}$ stretching modes. Experimentally a narrow band is present at $3660 \mathrm{~cm}^{-1}$ upon hydroxylation of dehydrated samples which is assigned to the stretching of free $\mathrm{NbO}-\mathrm{H}$ groups ${ }^{24}$. Lower values indicate hydrogen bonding: $3567 \mathrm{~cm}^{-1}$ (distance $\mathrm{O} \ldots \mathrm{H}=2.133 \AA$ ) and $3267 \mathrm{~cm}^{-1}$ (distance $\mathrm{O} \ldots \mathrm{H}=1.720 \AA$ ). One particular case is observed for $\mathrm{Nb} 2-\mathrm{Structure} 4$, Table $\mathbf{S 2}$, for which the NbO-H stretching mode is assigned to a value of $2263 \mathrm{~cm}^{-1}$.

The region between $1000 \mathrm{~cm}^{-1}$ and $800 \mathrm{~cm}^{-1}$ is dominated by $\mathrm{Nb}=\mathrm{O}, \mathrm{Nb}-\mathrm{O}-\mathrm{Si}, \mathrm{Si}-\mathrm{O}-\mathrm{Si}$ stretching modes. From the calculated $\mathrm{Nb}=\mathrm{O}$ distances, the vibration frequencies can be obtained in first approximation using the relationship of Hardcastle et al. ${ }^{33} \mathrm{Nb}=\mathrm{O}$ bonds, with distances of $1.76-1.79 \AA$ for one $\mathrm{Nb}$ atom grafted to silica surface, are predicted to vibrate between $(906-941 \pm 30) \mathrm{cm}^{-1}$ in first approximation. From our calculations we have found that the vibration frequencies for $\mathrm{Nb}=\mathrm{O}$ bonds (one $\mathrm{Nb}$ atom grafted to silica surface) are between $1009-964 \mathrm{~cm}^{-1}$ which is in very good agreement with experimental work. ${ }^{13,14}$ Experimentally, the $\mathrm{Nb}=\mathrm{O}$ vibration is observed at $982 \mathrm{~cm}^{-1}$ on dehydrated $10 \% \mathrm{Nb}_{2} \mathrm{O}_{5} /$ Silica $^{13,14}$ and on dehydrated $\mathrm{Nb}-\mathrm{MCM}-41$ at $\sim 985 \mathrm{~cm}^{-1} .^{13}$

The difference between the experimental and theoretical data is that, the calculated vibrations are slightly overestimated with respect to the bands observed due to the use of the DFT method and the harmonic approximation for the calculation of the vibrational frequencies.

For the case when two $\mathrm{Nb}$ atoms are grafted on a double silica unit cell model surface, the vibrational frequencies for $\mathrm{Nb}=\mathrm{O}$ are between $835-905 \mathrm{~cm}^{-1}$. The region between $700-600 \mathrm{~cm}^{-1}$ is dominated by $\mathrm{Nb}-\mathrm{OH}$ stretching of the $\mathrm{O}$ atom or bending of the $\mathrm{H}$ atom. The region below $600 \mathrm{~cm}^{-1}$ corresponds again to the $\mathrm{Nb}-\mathrm{O}-\mathrm{Si}, \mathrm{Si}-\mathrm{O}-\mathrm{Si}$ stretching modes. For a better understanding of the normal modes we compared them with the 
experimental infrared spectrum for the case when two $\mathrm{Nb}$ are grafted on silica (see Figure S1 and 9).

From Fig. S1 (See Supplementary Material), it can be observed that the surface infrared vibrational spectra can be divided into three regions: the high frequency domain between $4000-3000 \mathrm{~cm}^{-1}$, the middle frequency domain between $2000-1500 \mathrm{~cm}^{-1}$, the small frequency domain between $1500-500 \mathrm{~cm}^{-1}$. The interval $3000-2000 \mathrm{~cm}^{-1}$ is void of any frequency in our case.

In the high frequency domain $\left(4000-3000 \mathrm{~cm}^{-1}\right)$ we find a strong infrared active $\mathrm{OH}$ stretching vibration at $3770 \mathrm{~cm}^{-1}$. The vibration of the $\mathrm{OH}$ stretching bond found at $3770 \mathrm{~cm}^{-1}$ is in the range of a free $\mathrm{OH}$ stretching vibration $3600-3800 \mathrm{~cm}^{-1}$. In the middle frequency domain we do not observe any frequency in our case.

Unlike the previous regions, in the $1500-500 \mathrm{~cm}^{-1}$ region, one can no longer assign a frequency to a single bond formation. Rather, in the so-called fingerprint region, several bonds are found to vibrate at nearly the same frequency giving rise to complex normal modes not easy to describe. With this in mind, we point however, towards the large presence of the $\mathrm{Nb}=\mathrm{O}, \mathrm{Nb}-\mathrm{O}-\mathrm{Si}, \mathrm{Si}-\mathrm{O}-\mathrm{Si}$ stretching modes.

Comparing these data with experiment (See Figure 9) the following can be concluded: In the experimental spectrum no absorbance is observed, between $2000-4000 \mathrm{~cm}^{-1}$, besides the $3740 \mathrm{~cm}^{-1}$ "large" band. This finding is in agreement with the theoretical models. No $\mathrm{Nb}=\mathrm{O}$ nor $\mathrm{Nb}-\mathrm{O}-\mathrm{Si}$ vibration is visible in IR (only visible with RAMAN). It was found earlier that the $v \mathrm{Si}-\mathrm{OH} \approx v \mathrm{Nb}-\mathrm{OH}^{30}$, with $\mathrm{Nb}$ in oxidation state +5 . The $\mathrm{Nb}$ $\mathrm{OH}$ bands being less intense than the $\mathrm{Si}-\mathrm{OH}$ band(s) due to the low concentration of $\mathrm{Nb}$, their signal is drawn in the spectrum, however, a tiny shoulder was observed in zeolitic materials ${ }^{30}$ at $3728 \mathrm{~cm}^{-1}$. Due to the equilibrium conditions between the dehydrated and hydrated $\mathrm{Nb}(\mathrm{V})$ Lewis acid and base pairs in/on silica (See Structure 1), show Nb-OH IR bands which are even weaker because their presence is related to the degree of ambient humidity.

The structures corresponding to the experimental spectrum are the structures A and E as concerns the monomers and structures 1, 3, 6, and 8 for the Lewis acid base pair structures. However, taking the degree of hydration into account on structure E is 
expected to be dominant in the monomer structures and structure 1 (most stable of the series) for the Lewis acid base pair structures. Both model structures show a $\mathrm{Nb}-\mathrm{OH}$ vibration of $3770 \mathrm{~cm}^{-1}$. The $\mathrm{Nb}-\mathrm{OH}$ bands are thus expected to overlap with the terminal silanol bands.

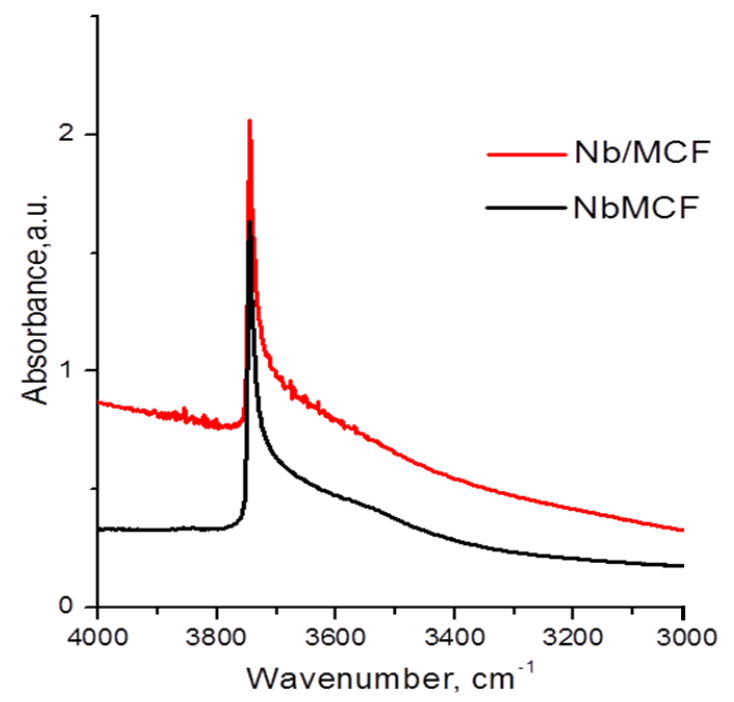

Figure 9. FTIR spectra of niobium containing mesoporous cellular foams ( $\mathrm{Nb} / \mathrm{MCF}$ prepared by the impregnation and NbMCF synthesized with the use of $\mathrm{Nb}$ source in one pot) activated under vacuum at $623 \mathrm{~K}$.

\section{Conclusion}

In this study the insertion and grafting of $\mathrm{Nb}$ oxide species as a function of the degree of hydration has been characterized at the molecular level using periodic DFT confronted with experimental results.

The comparison of calculations with the experimental results (UV-Vis) indicates that two $\mathrm{Nb}$ structures are favored when niobium is inserted into silica, structure A (mono coordinated) and E (penta coordinated). The method of insertion (grafting or isomorphous substitution during the synthesis) does not determine the species formed but the structure of silica is the important parameter. On amorphous silica penta coordinated species is not formed whereas in mesoporous cellular foams (MCF) containing cavities such a form is easily generated. Therefore the catalytic activity of 
niobium species located on amorphous silica and on ordered mesoporous molecular silica sieves is different.

The characterization of the earlier observed $\mathrm{Nb}$ Lewis acid base pairs in silica was achieved by constructing a large amorphous silica slab, which enabled the determination of the optimal distance between the Lewis acid and the Lewis base, and found to be about $9 \AA$. Its stability is probably depending on the local flexibility of the silica material. Moreover, the IR investigation provided a complete calculated spectrum between 500 and $4000 \mathrm{~cm}^{-1}$, from which the overlap between the bands of the $\mathrm{Nb}-\mathrm{OH}$ groups and the terminal silanol groups was confirmed, as was found for $\mathrm{Nb}$ substituted zeolites. 


\section{Acknowledgments}

This work was performed using HPC resources from GENCI- [CCRT/CINES/IDRIS] (Grant 2010-[x2010082022]) and the CCRE of Université Pierre et Marie Curie. COST action D36, WG No D36/0006/06 and the Polish Ministry of Science (Grant No. 118/COS/2007/03) are acknowledged for the financial support. The authors thank Magdalena Olejniczak and Martyna Zielińska for carrying out the spectroscopic measurements and Izabela Sobczak for valuable discussion.

\section{References}

1. Garcia-Sancho, C.; Sadaba, I.; Moreno-Tost, R.; Merida-Robles, J.; SantamariaGonzalez, J.; Lopez-Granados, M.; and Maireles-Torres, P., Dehydration of Xylose to Furfural over Mcm-41-Supported Niobium-Oxide Catalysts. Chemsuschem, 2013, 6, 635-642.

2. Radhakrishnan, R.; Wu, J.; Jaenicke, S.; and Chuah, G.K., Effects of Acidity and Pore Size Constraints on Supported Niobium Oxide Catalysts for the Selective Formation of Glycerol Monolaurate. Chemcatchem, 2011, 3, 761-770.

3. Onfroy, T.; Clet, G.; Bukallah, S.B.; Visser, T.; and Houalla, M., Acidity of Titania-Supported Tungsten or Niobium Oxide Catalysts - Correlation with Catalytic Activity. Applied Catalysis a-General, 2006, 298, 80-87.

4. Viparelli, P.; Ciambelli, P.; Lisi, L.; Ruoppolo, G.; Russo, G.; and Volta, J.C., Oxidative Dehydrogenation of Propane over Vanadium and Niobium Oxides Supported Catalysts. Applied Catalysis a-General, 1999, 184, 291-301.

5. Ziolek, M., Niobium-Containing Catalysts - the State of the Art. Catalysis Today, 2003, 78, 47-64.

6. Tanaka, T.; Takenaka, S.; Funabiki, T.; and Yoshida, S., Selective Formation of Acetal by Photooxidation of Ethanol over Silica-Supported Niobium Oxide Catalysts. Chemistry Letters, 1994, 809-812.

7. Tanabe, K. and Lizuka, T., Catalytic Properties of Niobium Compounds, Part I. Vol. NbTR-03/1983. 1983.

8. Nowak, I. and Ziolek, M., Niobium Compounds: Preparation, Characterization, and Application in Heterogeneous Catalysis. Chemical Reviews, 1999, 99, 3603 3624.

9. Kobayashi, H.; Yamaguchi, M.; Tanaka, T.; Nishimura, Y.; Kawakami, H.; and Yoshida, S., Quantum Chemical Study of Metal-Oxide Catalysts - Structures of Vanadium-Oxide and Niobium Oxide Clusters Supported on Silica and Alumina. Journal of Physical Chemistry, 1988, 92, 2516-2520.

10. Jehng, J.M. and Wachs, I.E., Niobium Oxalate - a New Precursor for the Preparation of Supported Niobium Oxide Catalysts. Abstracts of Papers of the American Chemical Society, 1989, 198, 48-CATL.

11. Jehng, J.M. and Wachs, I.E., Niobium Oxalate - New Precursor for Preparation of Supported Niobium Oxide Catalysts. Acs Symposium Series, 1990, 437, 232242. 
12. Jehng, J.M. and Wachs, I.E., Molecular-Structures of Supported Niobium Oxide Catalysts under Insitu Conditions. Journal of Physical Chemistry, 1991, 95, 7373-7379.

13. Burcham, L.J.; Datka, J.; and Wachs, I.E., In Situ Vibrational Spectroscopy Studies of Supported Niobium Oxide Catalysts. Journal of Physical Chemistry $B, \mathbf{1 9 9 9}, 103,6015-6024$.

14. Jehng, J.M. and Wachs, I.E., Molecular Design of Supported Niobium Oxide Catalysts. Catalysis Today, 1993, 16, 417-426.

15. Datka, J.; Turek, A.M.; Jehng, J.M.; and Wachs, I.E., Acidic Properties of Supported Niobium Oxide Catalysts - an Infrared-Spectroscopy Investigation. Journal of Catalysis, 1992, 135, 186-199.

16. Denofre, S.; Gushikem, Y.; Decastro, S.C.; and Kawano, Y., Stability and Surface-Acidity of Niobium(V) Oxide Grafted on a Silica-Gel Surface. Journal of the Chemical Society-Faraday Transactions, 1993, 89, 1057-1061.

17. Kawano, Y.; Denofre, S.; and Gushikem, Y., Raman and Infrared-Spectra of Silica-Gel and Niobium(V) Oxide Grafted on Silica-Gel Surface and Their Dependence on Pretreatment Temperatures. Vibrational Spectroscopy, 1994, 7, 293-302.

18. Pereira, E.B.; Pereira, M.M.; Lam, Y.L.; Perez, C.A.C.; and Schmal, M., Synthesis and Characterization of Niobium Oxide Layers on Silica and the Interaction with Nickel. Applied Catalysis a-General, 2000, 197, 99-106.

19. Ko, E.I.; Bafrali, R.; Nuhfer, N.T.; and Wagner, N.J., The Use of a Niobia-Silica Surface Phase Oxide in Studying and Varying Metal Support Interactions in Supported Nickel-Catalysts. Journal of Catalysis, 1985, 95, 260-270.

20. Ichikuni, N.; Asakura, K.; and Iwasawa, Y., Preparation and Catalytic Properties of a New Sio2-Attached Nb-Dimer Catalyst - Regulation of Acidity Basicity by the Number of Metal Atoms in Surface-Active Sites. Journal of the Chemical Society-Chemical Communications, 1991, 112-113.

21. Nishimura, M.; Asakura, K.; and Iwasawa, Y., New Sio2-Supported Niobium Monomer Catalysts for Dehydrogenation of Ethanol. Journal of the Chemical Society-Chemical Communications, 1986, 1660-1661.

22. Asakura, K. and Iwasawa, Y., Synthesis, Characterization, and Catalytic Properties of Sio2-Attached One-Atomic-Layer Niobium Oxide Catalysts. Journal of Physical Chemistry, 1991, 95, 1711-1716.

23. Shirai, M.; Asakura, K.; and Iwasawa, Y., Monolayer Structures of Niobic Acids Supported on Sio2 and Their Catalytic Activities for Esterification of AceticAcid with Ethanol. Journal of Physical Chemistry, 1991, 95, 9999-10004.

24. Iizuka, T.; Ogasawara, K.; and Tanabe, K., Acidic and Catalytic Properties of Niobium Pentaoxide. Bulletin of the Chemical Society of Japan, 1983, 56, 29272931.

25. Lam, S.-M.; Sin, J.-C.; Satoshi, I.; Abdullah, A.Z.; and Mohamed, A.R., Enhanced Sunlight Photocatalytic Performance over Nb205/Zno Nanorod Composites and the Mechanism Study. Applied Catalysis a-General, 2014, 471, 126-135.

26. Esteves, A.; Oliveira, L.C.A.; Ramalho, T.C.; Goncalves, M.; Anastacio, A.S.; and Carvalho, H.W.P., New Materials Based on Modified Synthetic Nb2o5 as Photocatalyst for Oxidation of Organic Contaminants. Catalysis Communications, 2008, 10, 330-332.

27. Ziolek, M.; Sobczak, I.; Decyk, P.; Sobanska, K.; Pietrzyk, P.; and Sojka, Z., Search for Reactive Intermediates in Catalytic Oxidation with Hydrogen 
Peroxide over Amorphous Niobium(V) and Tantalum(V) Oxides. Applied Catalysis B-Environmental, 2015, 164, 288-296.

28. Iwasawa, Y., Characterization and Chemical Design of Oxide Surfaces. 11th International Congress on Catalysis - 40th Anniversary, Pts a and B, ed. Hightower, J.W., et al. Vol. 101. 1996. 21-34.

29. Verpoort, F.; Dedoncker, G.; Bossuyt, A.R.; Fiermans, L.; and Verdonck, L., Angle-Resolved and Depth Profiling Xps Investigation of a Monolayer Niobium Oxide Catalyst. Journal of Electron Spectroscopy and Related Phenomena, 1995, 73, 271-281.

30. Tielens, F.; Shishido, T.; and Dzwigaj, S., What Do the Niobium Framework Sites Look Like in Redox Zeolites? A Combined Theoretical and Experimental Investigation. Journal of Physical Chemistry C, 2010, 114, 3140-3147.

31. Gao, X.T.; Wachs, I.E.; Wong, M.S.; and Ying, J.Y., Structural and Reactivity Properties of Nb-Mcm-41: Comparison with That of Highly Dispersed Nb2o5/Sio2 Catalysts. Journal of Catalysis, 2001, 203, 18-24.

32. Islam, M.M.; Costa, D.; Calatayud, M.; and Tielens, F., Characterization of Supported Vanadium Oxide Species on Silica: A Periodic Dft Investigation. Journal of Physical Chemistry C, 2009, 113, 10740-10746.

33. Wojtaszek, A.; Sobczak, I.; Ziolek, M.; and Tielens, F., Gold Grafted to Mesoporous Silica Surfaces, a Molecular Picture. Journal of Physical Chemistry C, 2009, 113, 13855-13859.

34. Wojtaszek, A.; Sobczak, I.; Ziolek, M.; and Tielens, F., The Formation of Gold Clusters Supported on Mesoporous Silica Material Surfaces: A Molecular Picture. Journal of Physical Chemistry C, 2010, 114, 9002-9007.

35. Guesmi, H. and Tielens, F., Chromium Oxide Species Supported on Silica: A Representative Periodic Dft Model. Journal of Physical Chemistry C, 2012, 116, 994-1001.

36. Guesmi, H.; Gryboś, R.; Handzlik, J.; and Tielens, F., Characterization of Molybdenum Monomeric Oxide Species Supported on Hydroxylated Silica; a Dft Study. Physical Chemistry Chemical Physics, 2014, 16, 18253-18260.

37. Handzlik, J.; Grybos, R.; and Tielens, F., Structure of Monomeric Chromium(Vi) Oxide Species Supported on Silica: Periodic and Cluster Dft Studies. Journal of Physical Chemistry C, 2013, 117, 8138-8149.

38. Kresse, G. and Hafner, J., Ab-Initio Molecular-Dynamics for Liquid-Metals. Physical Review B, 1993, 47, 558-561.

39. Kresse, G. and Hafner, J., Ab-Initio Molecular-Dynamics Simulation of the Liquid-Metal Amorphous-Semiconductor Transition in Germanium. Physical Review B, 1994, 49, 14251-14269.

40. Perdew, J.P.; Burke, K.; and Ernzerhof, M., Generalized Gradient Approximation Made Simple (Vol 77, Pg 3865, 1996). Physical Review Letters, 1997, 78, 1396-1396.

41. Perdew, J.P.; Burke, K.; and Ernzerhof, M., Generalized Gradient Approximation Made Simple. Physical Review Letters, 1996, 77, 3865-3868.

42. Folliet, N.; Roiland, C.; Begu, S.; Aubert, A.; Mineva, T.; Goursot, A.; Selvaraj, K.; Duma, L.; Tielens, F.; Mauri, F.; Laurent, G.; Bonhomme, C.; Gervais, C.; Babonneau, F.; and Azais, T., Investigation of the Interface in SilicaEncapsulated Liposomes by Combining Solid State Nmr and First Principles Calculations. Journal of the American Chemical Society, 2011, 133, 1681516827. 
43. Costa, D.; Tielens, F.; Stievano, L.; and Lambert, J.F., Glycine Interaction with Geminal and Vicinal Silanols, in Theory and Applications of Computational Chemistry - 2008. 2009. p. 251-256.

44. Tielens, F.; Gervais, C.; Lambert, J.F.; Mauri, F.; and Costa, D., Ab Initio Study of the Hydroxylated Surface of Amorphous Silica: A Representative Model. Chemistry of Materials, 2008, 20, 3336-3344.

45. Blochl, P.E., Projector Augmented-Wave Method. Physical Review B, 1994, 50, 17953-17979.

46. Kresse, G. and Joubert, D., From Ultrasoft Pseudopotentials to the Projector Augmented-Wave Method. Physical Review B, 1999, 59, 1758-1775.

47. Schmidt-Winkel, P.; Lukens, W.W.; Yang, P.D.; Margolese, D.I.; Lettow, J.S.; Ying, J.Y.; and Stucky, G.D., Microemulsion Templating of Siliceous Mesostructured Cellular Foams with Well-Defined Ultralarge Mesopores. Chemistry of Materials, 2000, 12, 686-696.

48. Margolese, D.; Melero, J.A.; Christiansen, S.C.; Chmelka, B.F.; and Stucky, G.D., Direct Syntheses of Ordered Sba-15 Mesoporous Silica Containing Sulfonic Acid Groups. Chemistry of Materials, 2000, 12, 2448-2459.

49. Stawicka, K.; Trejda, M.; and Ziolek, M., The Production of Biofuels Additives on Sulphonated Mcf Materials Modified with $\mathrm{Nb}$ and Ta-Towards Efficient Solid Catalysts of Esterification. Applied Catalysis a-General, 2013, 467, 325-334.

50. Sobczak, I.; Kozlowska, M.; and Ziolek, M., Au Containing Mesostructured Cellular Foams Nbmcf and Zrmcf in Selective Oxidation of Methanol to Formaldehyde. Journal of Molecular Catalysis a-Chemical, 2014, 390, 114-124.

51. Wojtaszek-Gurdak, A. and Ziolek, M., Nb and Zr Modified Mww Zeolites Characterisation and Catalytic Activity. RSC Advances, 2015, 5, 22326-22333.

52. Boujday, S.; Lambert, J.F.; and Che, M., Amorphous Silica as a Versatile Supermolecular Ligand for Ni(Ii) Amine Complexes: Toward Interfacial Molecular Recognition. Chemphyschem, 2004, 5, 1003-1013.

53. Valencia, D.; Pena, L.; Uc, V.H.; and Garcia-Cruz, I., Metal-Support Interactions Revisited by Theoretical Calculations: The Influence of Organic Ligands for Preparing Ni/Sio2 Catalysts. Applied Catalysis a-General, 2014, 475, 134-139.

54. Sambrano, J.R.; Gracia, L.; Andres, J.; Berski, S.; and Beltran, A., A Theoretical Study on the Gas Phase Reactions of the Anions Nbo3-, Nbo5-, and Nbo2(0h)(2)(-) with H2o and O-2. Journal of Physical Chemistry A, 2004, 108, 10850-10860.

55. Hardcastle, F.D. and Wachs, I.E., Determination of Niobium Oxygen Bond Distances and Bond Orders by Raman-Spectroscopy. Solid State Ionics, 1991, 45, 201-213.

56. Ziolek, M.; Sobczak, I.; Nowak, I.; Decyk, P.; Lewandowska, A.; and Kujawa, J., Nb-Containing Mesoporous Molecular Sieves - a Possible Application in the Catalytic Processes. Microporous and Mesoporous Materials, 2000, 35-6, 195207.

57. Frisch, M.J.; Trucks, G.W.; Schlegel, H.B.; Scuseria, G.E.; Robb, M.A.; Cheeseman, J.R.; Montgomery, J., J. A.; Vreven, T.; Kudin, K.N.; Burant, J.C.; Millam, J.M.; Iyengar, S.S.; Tomasi, J.; Barone, V.; Mennucci, B.; Cossi, M.; Scalmani, G.; Rega, N.; Petersson, G.A.; Nakatsuji, H.; Hada, M.; Ehara, M.; Toyota, K.; Fukuda, R.; Hasegawa, J.; Ishida, M.; Nakajima, T.; Honda, Y.; Kitao, O.; Nakai, H.; Klene, M.; Li, X.; Knox, J.E.; Hratchian, H.P.; Cross, J.B.; Bakken, V.; Adamo, C.; Jaramillo, J.; Gomperts, R.; Stratmann, R.E.; Yazyev, O.; Austin, A.J.; Cammi, R.; Pomelli, C.; Ochterski, J.W.; Ayala, P.Y.; 
Morokuma, K.; Voth, G.A.; Salvador, P.; Dannenberg, J.J.; Zakrzewski, V.G.; Dapprich, S.; Daniels, A.D.; Strain, M.C.; Farkas, O.; Malick, D.K.; Rabuck, A.D.; Raghavachari, K.; Foresman, J.B.; Ortiz, J.V.; Cui, Q.; Baboul, A.G.; Clifford, S.; Cioslowski, J.; Stefanov, B.B.; Liu, G.; Liashenko, A.; Piskorz, P.; Komaromi, I.; Martin, R.L.; Fox, D.J.; Keith, T.; Al-Laham, M.A.; Peng, C.Y.; Nanayakkara, A.; Challacombe, M.; Gill, P.M.W.; Johnson, B.; Chen, W.; Wong, M.W.; Gonzalez, C.; and Pople, J.A., Gaussian 03, Revision C.02. 2004, Wallingford CT: Gaussian, Inc.

58. Bolis, V.; Fubini, B.; Marchese, L.; Martra, G.; and Costa, D., Hydrophilic and Hydrophobic Sites on Dehydrated Crystalline and Amorphous Silicas. Journal of the Chemical Society-Faraday Transactions, 1991, 87, 497-505.

59. Guyot, A.; Curtis, G.E.; and Libbey, W., Smithsonian Meteorological Tables: Based on Guyot's Meteorological and Physical Tables. 1896.

60. Halls, M.D.; Velkovski, J.; and Schlegel, H.B., Harmonic Frequency Scaling Factors for Hartree-Fock, S-Vwn, B-Lyp, B3-Lyp, B3-Pw91 and Mp2 with the Sadlej Pvtz Electric Property Basis Set. Theoretical Chemistry Accounts, 2001, 105, 413-421. 


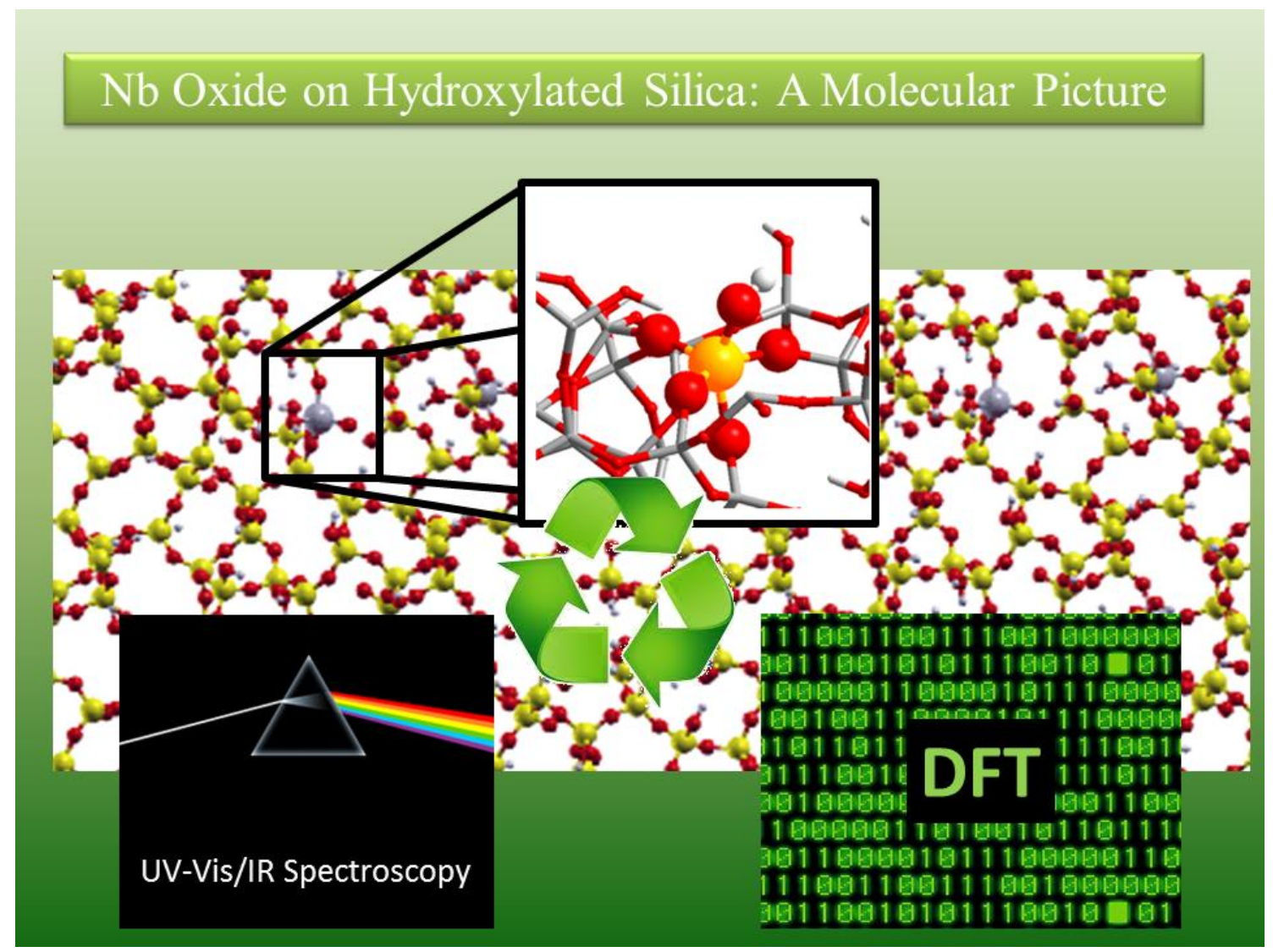

